\title{
Financial Conditions Index and Economic Performance in Nigeria
}

\author{
Chukwu Agwu Ejem $P h D$ \\ Senior Lecturer \\ Department of Banking and Finance \\ Abia State University, Uturu, Nigeria \\ E-mail: ecjah7I@yahoo.com \\ Udochukwu Godfrey Ogbonna $P h D$ \\ Senior Lecturer \\ Department of Management Science \\ Rhema University, Aba, Nigeria \\ E-mail: kellyogbo2004@yahoo.com
}

\begin{abstract}
The main aim of this study is to construct a financial conditions index for Nigeria and analyze its predictive power for future growth rate and inflationary trend. The study is based on yearly time series data from 1985 to 2018. The variables included in the construction of the index are riskless interest rate, stock market index, exchange rate, credit to private sector and interest rate spread. The weights attached to these variables are derived from ARDL coefficients, while the predictive power of the constructed index is examined within the VAR framework. The results from the ARDL model shows that credit to private sector and stock market index are the most significant factors for nominal GDP, hence having a substantial weight in the resultant financial conditions index. However, the results from VAR impulse response function and forecast error variance decomposition suggest that the constructed financial conditions index contain very little predictive information about future growth rate and inflationary trend.
\end{abstract}

Keywords: Financial Conditions Index, Inflation, Real GDP Growth Rate.

\section{Introduction}

Understanding how monetary policy shocks transmit to the real economy is an age long issue, and has continued to attract scholarly debate in both developing and developed countries. Traditionally, changes in monetary policy stance affect savings and investment behaviours of both households and firms through interest rates and exchange rate. Hence, monetary conditions index, which reflects changes in monetary conditions related to interest rate and exchange, was used during the I990s to track monetary policy stance.

However, the rapidly growing complexities of financial systems all over the world have necessitated a more comprehensive index that accommodates the impact of financial markets in the monetary policy transmission mechanism (Swiston, 2008). More specifically, since early 2000s, there is a growing body of evidence suggesting that financial conditions index provides a more useful tool for forecasting the performance of real economic variables, especially, where interest rates and exchange rate are found insufficient (Angelopoulou, Balfoussia\& Gibson, 20I4). Therefore, financial conditions index is,not only a natural extension of monetary conditions index, but also, a more comprehensive index that accommodates the importance of asset prices (equity and property prices) in the monetary policy transmission mechanism (Angelopoulou, Balfoussia\& Gibson, 20I4).

This study constructs a financial conditions index for Nigeria and examining its predictive power for both inflation and growth rate in real GDP using yearly time series data from I985 to 2018. While the financial conditions index was constructed based on ARDL model which is novel in the literature, its predictive power for inflation is examined based on structural vector autoregressive model.

The remainder of this study has the following structure: The next section reviews the extant literature on financegrowth relationship as well as financial conditions index. Section 3 describes the data, models and methods; section 4 contains empirical analysis and discussion while the study is concluded in section 5. 


\section{Literature Review}

\section{I Financial Conditions Indicators and Economic Growth}

The relationship between financial conditions indicators and economic growth can be examined in the context of supply leading theory. The supply leading theory, which was initially due to Schumpeter (I9I2), and popularized by Levine and King (I997), states financial development is a precursor for and causes economic growth. If savings are efficiently mobilized and channelled into productive activities, there would be a significant increase in economic growth. Although, numerous studies (both in Nigeria and other developing and developed countries) have subjected this theoretical assertion to empirical tests, there is not yet a consensus. However, recent evidence reported in the empirical literature tends to support the view that financial sector development can trigger economic growth. These studies include Ipeghan and Marshall (2019), Olaniyan(2019), Ncanywa and Mabusela(2019), Olayungbo and Quadri(2019) and Okunlola, Masade, Folaranmi Lukman and Ajayi Abiodun(2020).

Ibrahim, Abdullahi, Azman-Saini and Rahman (2017) employed the dynamic panel GMM method to investigate the effects of both banking sector and stock market developments on economic growth for 53 countries from I988 to 2012. Consistent with the supply-leading hypothesis, they found that both stock market and banking sector developments are necessary ingredients for economic growth.

Ipeghan and Marshall (2019) contributed to the finance-growth literature by empirically testing the effects capital market and credit market on economic growth using Nigerian data at yearly frequency spanning from I98I to 2017. Using the Johansen cointegrating framework and pairwise Granger causality test, they found that both capital market and banking sector development scan significantly affect, and are cointegrated with, economic growth.

Olaniyan(2019) used the instrumental generalized method of moment approach to examine the finance-growth relationship in Nigeria from 1977 to 2017 . He incorporated the interactive effect of remittances and financial development in the growth model and argues that it can improve growth estimate. Fitting the resultant growth model to yearly data obtained from the World Development Indicators database reveals that although, both remittances and financial development (credit to private sector ratio to GDP) individually affect economic growth negatively, their interaction plays a positive and highly significant role in the growth model.

Ncanywa and Mabusela(2019)employed the dynamic panel ARDL framework to test the link between financial development and economic growth in five sub-Saharan African countries; namely, Ghana, Kenya, Botswana, Nigeria and South Africa, using yearly data from I980 to 2014. They found the presence of both short run and long run relationship between financial development and economic growth, with credit to private sector and bank liquid liabilities both exerting a positive long run effect on economic growth, while domestic savings exerts a negative effect.

Olayungbo and Quadri(2019)employed both the Pooled Mean Group ARDL framework to model the relationship between financial development and economic growth incorporating the both the direct and interaction effect of remittances. The study focuses on sub-Saharan countries and is based on yearly data for 20 countries from 2000 to 2015 which were collected from the World Development Indicators data based. They found amongst others that both financial development and remittances exhibit a positive effect on economic growth.

More recently, Okunlola, Masade, Folaranmi Lukman and Ajayi Abiodun(2020)examined the finance-growth nexus in Nigeria using the causality framework developed by Toda and Yamamoto (I995) which is based on augmented VAR. Based on yearly data from 1985 to 2015 collected from CBN, NBS and NSE, they find evidence supporting the supply-leading theory which asserts that the level of financial development matters for economic growth.

\subsection{Financial Conditions Index and Economic Performance}

There is a growing body of literature on the relationship between financial conditions index and the behaviour of real economic variables. What appears to be the emerging consensus is that financial conditions index can usefully predict future direction of economic variables such as growth rate in real GDP and level of inflation. However, it appears that no recent empirical study has focused in line of inquiry in Nigeria.

Swiston (2008) employs VAR based impulse-response functions to construct a financial conditions index for US. They found that credit availability is an important driver of the business cycle, and accounts for more than $20 \%$ of the typical contribution of financial variables to economic growth. They also found that the constructed financial conditions index is a precise predictor of real GDP growth.

Khundrakpam, Kavediya and Anthony (2017) constructed financial condition indices for India and evaluated their ability to predict business cycle. They examined whether financial conditions index constructed based on principal component analysis (PCA) can predict economic growth rate better than financial conditions index constructed based on vector autoregressive (VAR) model. Their results show that PCA-based financial conditions index outperforms VAR-based financial conditions index.

Using a time-varying factor augmented vector autoregressive models with stochastic volatility Wang, Xu and Chen (2018) constructed a financial conditions index for China and examine its relationship with future inflation. Based on monthly 
data spanning from January 2002 to January 2015, they found that financial conditions index is useful in predicting future inflation.

Kabundi and Mbelu (2020) constructed a financial conditions index for South Africa using monthly time series data January 2000 to April 2017. The index was constructed based on time-varying principal component factor model proposed by Koop and Korobilis (20I4). They also specified and estimated a three-factor time-varying parameter factor-augmented vector autoregressive (TVP-FAVAR) model incorporating financial conditions index, headline inflation and GDP growth rate. They found amongst others that tighter financial conditions reduce both economic growth rate and level of inflation.

\section{Empirical Strategy}

\section{I Data Description}

In this study, yearly time series data from 1985 to 2018 are used. The study variables are inflation, nominal GDP, real GDP growth rate, riskless interest rate (Treasury bill rate), stock market index (All share indexes), average official exchange rate, credit to private sector and interest rate spread (prime lending rate minus monetary policy rate). All data were sourced from the annual statistical bulletin of the Central Bank of Nigeria and are analyzed using the E-Views software package.

Consistent with the extant literature, we construct the financial conditions index using the following formula.

$$
F C I=\sum_{j=1}^{n} w_{j}\left(x_{j, t}-\bar{x}_{\jmath}\right)
$$

Where FCI $=$ financial conditions index, $x_{j, t}=$ financial conditions variable $j$ at time $t, \bar{x}_{j}=$ mean of $x_{j}$ and $w_{j}$ is the weight attached to each $x_{j}$. Here, $x_{j}$ includes riskless interest rate (TBR), stock market index (ASI), exchange rate (EXR), credit to private sector (CPS) and interest rate spread (SPREAD).

Figure I shows the time series plot of the data. As this Figure shows, while nominal GDP, average official exchange rate, stock market index and credit to private sector show an upward trend, real GDP growth rate, inflation, and interest rate spread appear to be stationary. Riskless interest rate appears to follow a random walk with drift, increasing initially up to 1993 but showed a steady decline with observable fluctuations. However, it showed an upward trend from 2009. All these suggest that our variables have different levels of integration; hence there is good reason to model the relationship between financial conditions variables and economic growth within an ARDL framework.

GDPG

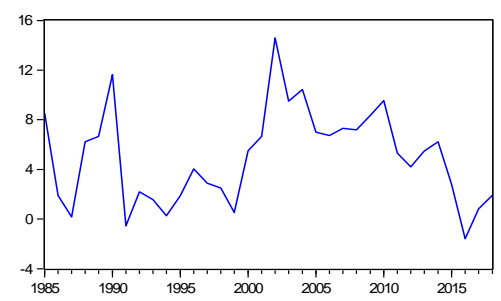

TBR
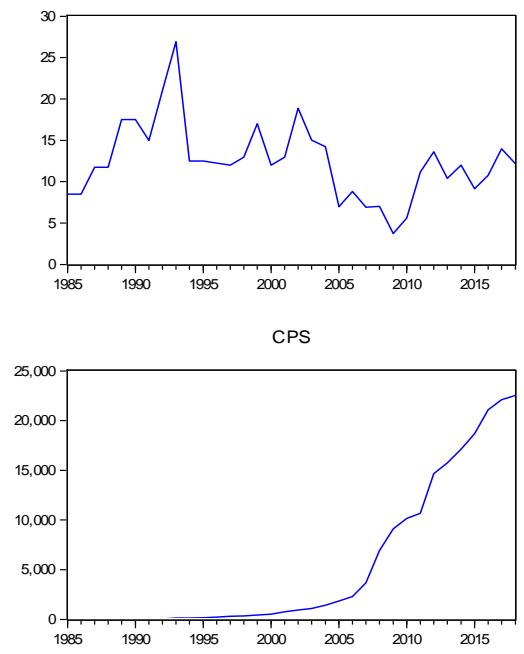

INFL

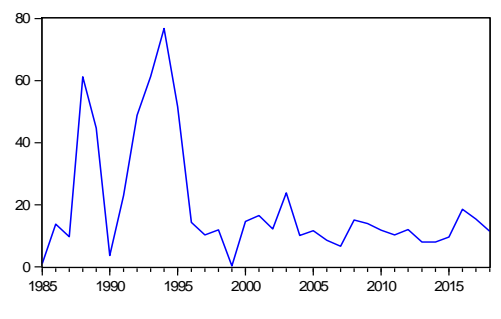

AOEXR
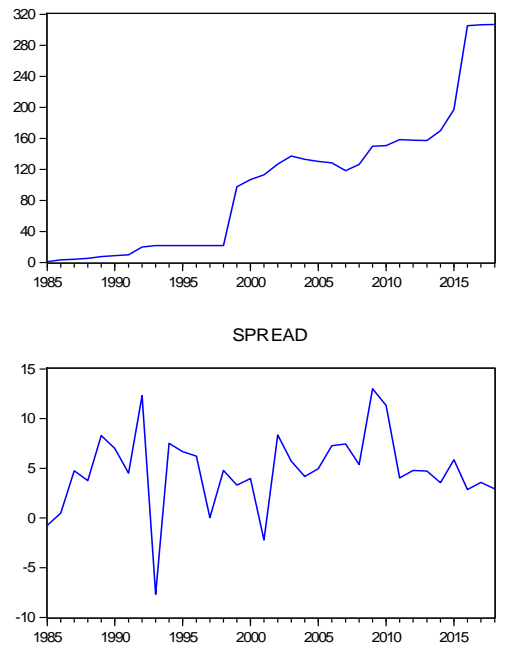

GDP

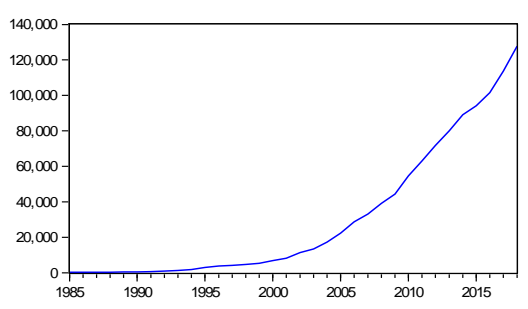

ASI

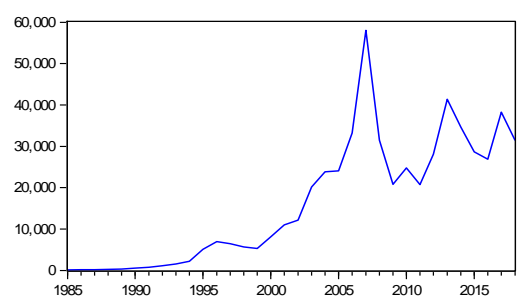

FigureI. Time Series Plot for the Study Variables 


\subsection{Methods}

To the estimate the relative impact of each financial conditions variable on nominal GDP, we employ the Autoregressive Distributive Lag (ARDL) framework. Compared with other dynamic time series frameworks, this dynamic estimation framework, which is novel in the literature in the context of constructing a financial conditions index, is employed basically because of its ability to accommodate time series variables that have different orders of integration in the same empirical model We specify our simple ARDL models as follows:

$$
\begin{gathered}
G D P_{t}=\alpha_{0}+\alpha_{1} G D P_{t-1}+\alpha_{2} T_{B}+\alpha_{3} T B R_{t-1}+\alpha_{4} A S I_{t}+\alpha_{5} A S I_{t-1}+\alpha_{6} E X R_{t}+\alpha_{7} E X R_{t-1}+\alpha_{8} C P S_{t} \\
+\alpha_{9} C P S_{t-1}+\alpha_{10} S P R E A D_{t}+\alpha_{11} S P R E A D_{t-1}+\epsilon_{t}
\end{gathered}
$$

Where $\alpha_{0}$ is the regression intercept and $\alpha_{1}$ is the autoregressive coefficient capturing the effect of lagged nominal GDP. Further, $\alpha_{2}$ and $\alpha_{3}$ are model coefficients that capture the concurrent and lagged effects of riskless interest rate, $\alpha_{4}$ and $\alpha_{5}$ are model coefficients that capture the concurrent and lagged effects of stock market index, $\alpha_{6}$ and $\alpha_{7}$ are model coefficients that capture the concurrent and lagged effects of exchange rate, $\alpha_{8}$ and $\alpha_{9}$ are model coefficients that capture the concurrent and lagged effects of credit to private sector, $\alpha_{10}$ and $\alpha_{11}$ are model coefficients that capture the concurrent and lagged effects of interest rate spread, and $\epsilon_{t}$ is the classical disturbance term.

For each variable, we use the total effect (sum of the concurrent and lagged coefficients) on nominal GDP as its relative weight in the construction of financial conditions index.

To examine whether financial conditions index can predict future economic performance, we employ the vector autoregressive (VAR) framework. The three variable reduced form VAR(I) financial conditions index, log of inflation and real GDP growth rate is specified as follows:

$$
\begin{gathered}
R G D P D_{t}=\beta_{01}+\beta_{11} R G D P G_{t-1}+\beta_{21} L I N F L_{t-1}+\beta_{31} F C I_{t-1}+\varepsilon_{1 t} \\
L I N F L_{t}=\beta_{02}+\beta_{12} R G D P G_{t-1}+\beta_{22} L I N F L_{t-1}+\beta_{32} F C I_{t-1}+\varepsilon_{2 t} \\
F C I_{t}=\beta_{03}+\beta_{13} R G D P G_{t-1}+\beta_{23} L I N F L_{t-1}+\beta_{33} F C I_{t-1}+\varepsilon_{3 t}
\end{gathered}
$$

Although, VAR order is typically selected based on some information criteria, we selected order I on rule of thumb basis, particularly because of the frequency of our data.

\section{Empirical Results and Discussion}

\section{I Summary Statistics}

\begin{tabular}{|c|c|c|c|c|c|c|c|}
\hline Variable & $\overline{\mathbf{x}}$ & Max & Min & $\boldsymbol{\sigma}$ & $\mathbf{S}$ & $\mathbf{K}$ & JB stat \\
\hline Growth Rate & 4.95 & 14.60 & -1.58 & 3.81 & 0.38 & 2.63 & $1.0292(0.5977)$ \\
\hline Inflation & 19.69 & 76.76 & 0.22 & I8.92 & 1.68 & 4.68 & $19.9173(0.0000)$ \\
\hline Nominal GDP & 30794.20 & $\mathrm{I} 27762.50$ & 192.27 & 38661.73 & I.I3 & 2.94 & $7.186 \mathrm{I}(0.0275)$ \\
\hline Treasury Bills Rate & $\mathrm{I} 2.44$ & 26.90 & 3.72 & 4.59 & 0.84 & 4.52 & $7.2417(0.0268)$ \\
\hline Exchange Rate & I0I.96 & 306.92 & 0.96 & 90.14 & 0.74 & 2.96 & $3.1346(0.2086)$ \\
\hline Stock Market Index & 16298.33 & 57990.20 & $\mathrm{I} 27.30$ & 15238.20 & 0.68 & $2.7 \mathrm{I}$ & $2.768 \mathrm{I}(0.2506)$ \\
\hline $\begin{array}{l}\text { Credit to Private } \\
\text { Sector }\end{array}$ & 5391.61 & 22521.93 & 13.07 & 7650.56 & I.I7 & $2.8 \mathrm{I}$ & $7.792 \mathrm{I}(0.0203)$ \\
\hline Spread & 4.79 & 12.99 & -7.68 & 3.95 & -0.62 & $4.9 \mathrm{I}$ & $7.3185(0.0258)$ \\
\hline
\end{tabular}

The descriptive summary of the data is presented in Table I. exchange The descriptive statistics shows that apart from real GDP growth rate, exchange rate and stock market index, all other series have a distribution that significantly deviates from normal distribution.

Table I. Statistical Summary of the Variables 


\section{I Financial Conditions Variables and Economic Growth}

Table 2 shows the results of the estimated optimal ARDL model for the relationship between financial conditions variables (treasury bill rate, stock market index, exchange rate, spread and credit to private sector) and nominal gross domestic product. The lag selection for each variable is based on Schwarz information criterion. As stated in the previous section, the estimated betas would be used as weightings for the construction of financial conditions index. The estimation is based on Newey-West standard errors which are consistent even in the presence of autocorrelation and heteroskedasticity.

Table 2. Short Run and Long Run Results for Finance and Growth; p-values in ( )

\begin{tabular}{cccc}
\hline Variable & Short Run Coefficient & Long Run Coefficient & Total \\
\hline GDP(-I $)$ & $0.4294(0.0180)$ & - & - \\
& & & \\
\hline TBR & $0.0612(0.085 \mathrm{I})$ & $0.1074(0.0979)$ & 0.1687 \\
\hline ASI & $0.1908(0.0035)$ & $0.3345(0.0000)$ & 0.5253 \\
\hline EXR & $0.0504(0.0563)$ & $0.0884(0.1537)$ & 0.1389 \\
\hline CPS & $0.1166(0.0690)$ & $0.5549(0.0000)$ & 0.6715 \\
\hline SPREAD & $-0.0374(0.1103)$ & $-0.0656(0.2060)$ & $-0.103 \mathrm{I}$ \\
\hline CointEq(-I) & $-0.5705(0.0025)$ & - & - \\
\hline Constant & - & $2.0663(0.0000)$ & - \\
\hline
\end{tabular}

As Table 2 shows, our regression results are striking in many ways. First, the coefficient on GDP(-I)(beta $=0.4294$, $\mathrm{p}$-value $=0.0180)$ is positive and statistically different from zero at $5 \%$ significance level, indicating that lagged nominal gross domestic product is a positive determinant of current nominal gross domestic product. A I\% increase in the nominal GDP in the current period would lead to approximately $0.43 \%$ increase in the next period nominal GDP, holding the impact of financial conditions variables constant. Thus, initial growth level affects the current growth. Secondly, focusing on the short run results, we can see that nominal GDP is positively related to riskless interest rate (beta $=0.06 \mathrm{I} 2$ ), stock market index (beta $=0.1908$ ), exchange rate (beta $=0.0504)$ and credit to private sector (beta $=0.1166)$, while it is negatively related to interest rate spread (beta $=-0.0374)$. Further, while the effect of stock market index (p-value 0.0035) is highly statistically significant, the effects of riskless interest rate ( $\mathrm{p}$-value $0.085 \mathrm{I}$ ), exchange rate ( $\mathrm{p}$-value 0.0563 ) and private sector credit ( $\mathrm{p}$-value 0.0690$)$ all are significant at 10\% level. However, the level of significance of the effect of interest rate spread ( $p$-value 0.I I03) exceeds all customary levels. These results suggest that relatively, capital market has the highest beneficial impact on nominal GDP, followed by private sector credit, and then by riskless interest rate, while exchange rate has the least beneficial impact. However, an increase in interest rate spread would marginally reduce nominal GDP.

Thirdly, the error correction term (CointEq(-I) $=-0.5705$, p-value $=0.0025)$ has the expected negative sign, and is also quite large and highly statistically significant, indicating that the estimated nominal GDP model can quickly attain equilibrium in the long run despite any short run disturbances, and the speed of adjustment is about $57 \%$ per annum. Finally, the long run results are largely comparable with those of the short run, especially in terms of the signs of the coefficients. However, while the long run effects of stock market index (beta $=0.3345$, p-value $=0.0000)$ and credit to private sector (beta $=0.5549$, p-value $=0.0000$ ) are the most significant in statistical sense, the beta associated with the latter is substantially higher in size than the former, suggesting that it has the largest long run beneficial impact. More, specifically, holding riskless interest rate, exchange rate and interest rate spread constant, a I\% increase in stock market index would concurrently increase nominal GDP by approximately $0.33 \%$, while a I\% increase in credit to private sector would lead to approximately $0.55 \%$ increase in nominal GDP. However, the long run coefficients on riskless interest rate, exchange rate and interest rate spread are estimated at $0.1074,0.0884$ and -0.0636 with associated p-values of $0.0979,0.1537$ and 0.2060 ), suggesting that they are relatively small and their effects on nominal GDP are not statistically significant at $5 \%$ level. The long run effect of riskless interest rate is significant at I0\% level. The long run intercept term (beta $=2.0663$, p-value $=0.0000$ ) is positive and highly significant, suggesting that on average, Nigeria would record significant economic growth even when all included financial conditions indicators are kept dormant.

Overall, our results suggest that financial conditions variables have a significant effect on economic growth in Nigeria both in the short run and in the long run. Also, credit to private sector and stock market index are the most significant factors for nominal GDP, hence have the highest weights in the construction of the financial conditions index. This evidence is, therefore, consistent with both credit and asset price channels of monetary policy transmission mechanism. This finding also agrees with the supply leading theory of finance-growth relationship as well as several previous studies including Acaravci,Ozturk 
and Acaravci(2007), Al-Malkawi and Abdullah(20I I), Ibrahim, Abdullahi, Azman-Saini and Rahman(20I7) and Oro and Alagidede(2018), Ipeghan and Marshall(2019)and Olaniyan (2019).

\subsection{Financial Conditions Index and Economic Performance}

Figure 2 shows the financial conditions index for Nigeria using the ARDL coefficients as weights. As this Figure shows, the constructed financial conditions index showed a steady upward trend from negative values to positive values over the sampled period. Specifically, the negative values of the index were recorded 'between' I985 to I999, suggesting that before the advent of the current democracy, Nigeria's financial conditions were on average looser than the prevailing macroeconomic conditions. On the contrary, the positive values recorded from 2000 to 2018 shows that Nigeria's financial conditions gradually become tighter than the prevailing macroeconomic conditions in the post democracy period.

\section{$\mathrm{FCl}$}

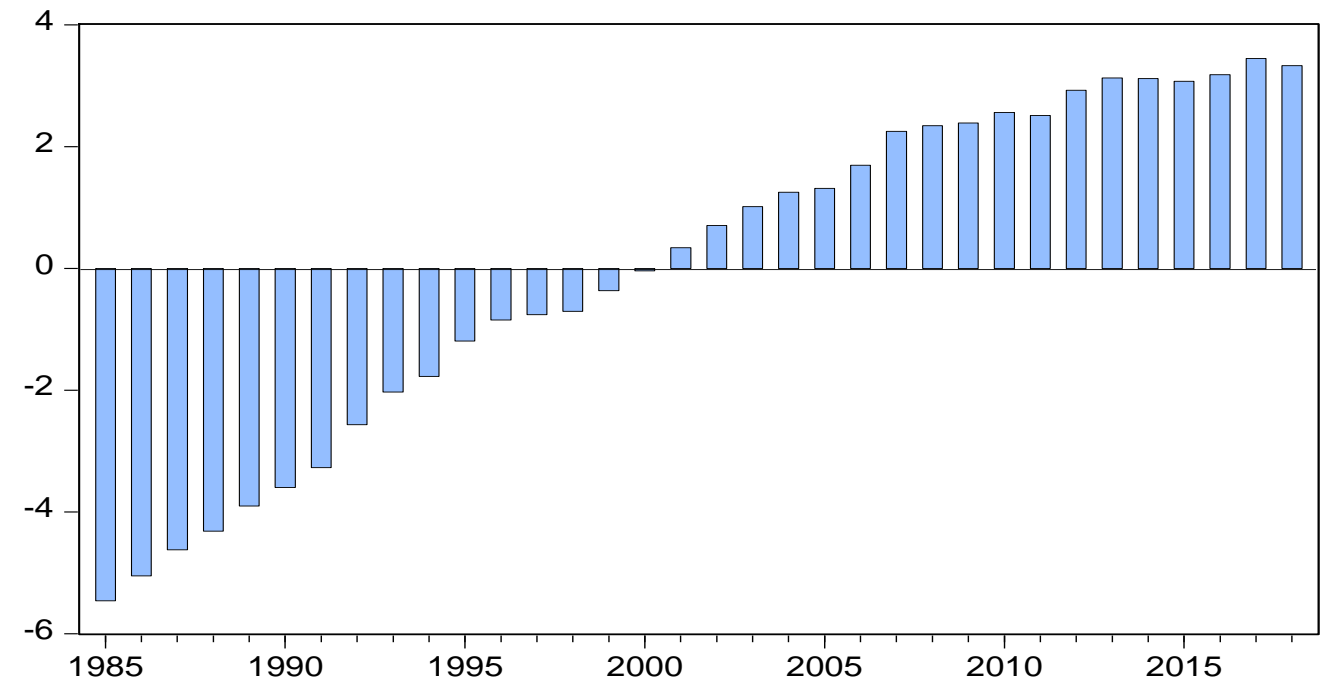

Figure 2. Financial Conditions Index for Nigeria

Table 3 shows the three variable $\operatorname{VAR}(\mathrm{I})$ results for the dynamic relationships between financial conditions index, inflation and real GDP growth rate. The p-values are obtained from the system equations estimated via OLS method. Figure 3shows the VAR inverted roots with respect to unit circle. Figures 4 and 5 show the impulse response function and variance decomposition of real GDP growth rate, inflation and financial conditions index.

From Table 3, we can see that both the autocorrelation ( $p$-value $=0.2646)$ and heteroskedasticity $(p$-value $=0.4620)$ test statistics are associated with a probability, hence not rejecting the null hypotheses of no serial correlation and heteroskedasticity. The inverted VAR roots in Figure 3 are all inside the unit circle which shows that the estimated VAR model is stable and can be used for structural analysis.

From Figure 4, we can see that while real GDP growth rate responded positively to a one standard deviation shocks in financial conditions index, inflation rate responded negatively. However, for both real economic variables, the impact of fin ancial conditions index is marginal throughout the impact period, hence, lacks economic significance. The forecast error variance decomposition of real GDP growth in Figure 5 shows that financial conditions index contributed less than $0.02 \%$ of the variance of real GDP growth throughout the forecast period, while it contributed approximately $0.07 \%$ of the variance of inflation rate in the fourth period. These results imply that financial conditions index has a little or no predictive power for both economic growth and inflation in Nigeria. Our results, therefore, contradict the recent findings of Wang, Xu and Chen (20I8) and Kabundi and Mbelu (2020) for China and South Africa respectively. We argue that the method of constructing the financial conditions index can plausibly explain these differing results.

Table 3. VAR Results for FCI and Economic Performance; p-value in ( )

\begin{tabular}{llll}
\hline Variable & RGDPG & LINFL & FCI \\
\hline GDPG(-I $)$ & $0.5053(0.0222)$ & $-0.0220(0.6469)$ & $-0.0060(0.4396)$ \\
\hline LINFL(-I) & $0.4962(0.3650)$ & $0.1566(0.3384)$ & $0.0170(0.5220)$ \\
\hline
\end{tabular}




\begin{tabular}{lccc}
\hline FCI $(-\mathrm{I})$ & $0.1597(0.4673)$ & $-0.0894(0.1745)$ & $0.9602(0.0000)$ \\
\hline Constant & $1.0476(0.5646)$ & $2.3245(0.0000)$ & $0.2493(0.0059)$ \\
\hline LM (2) statistic & & $11.164(0.2646)$ \\
\hline Heteroskedasticity Test & $36.143(0.4620)$ \\
\hline
\end{tabular}

Inverse Roots of AR Characteristic Polynomial

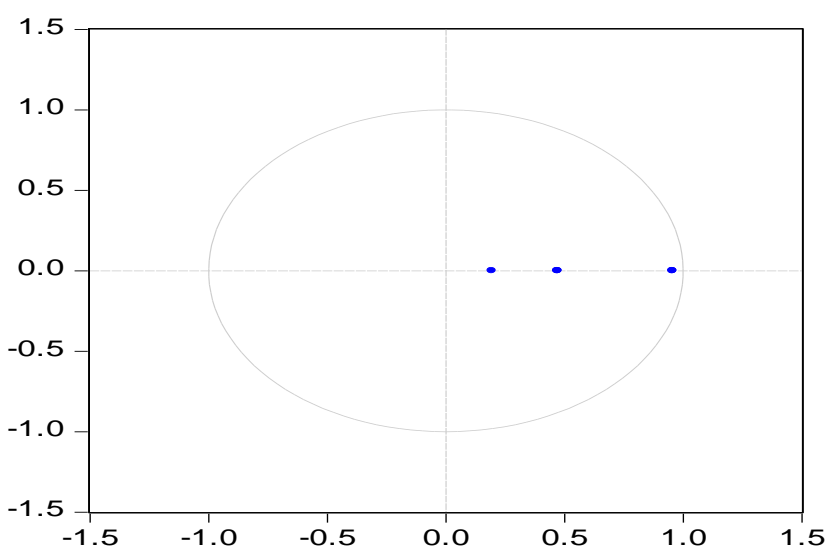

Figure 3. Inverted AR Characteristic Roots

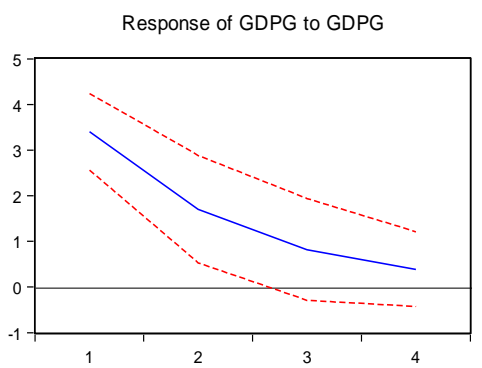

Response to Cholesky One S.D. Innovations \pm 2 S.E.
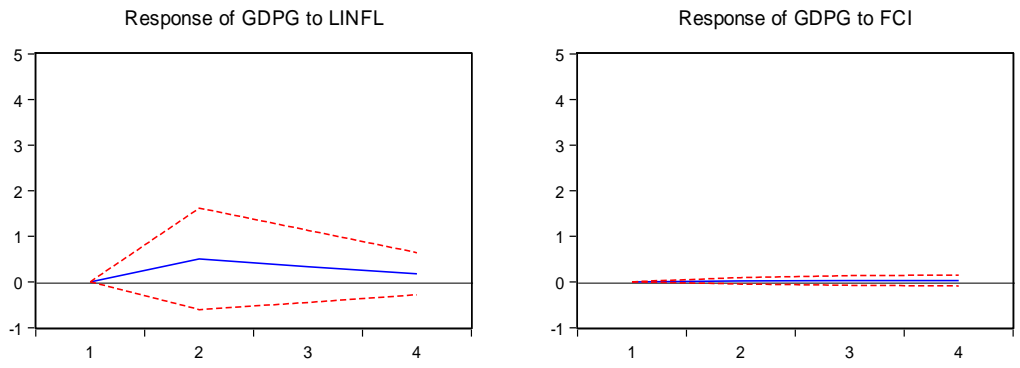

Response of LINFL to GDPG

Response of LINFL to LINFL
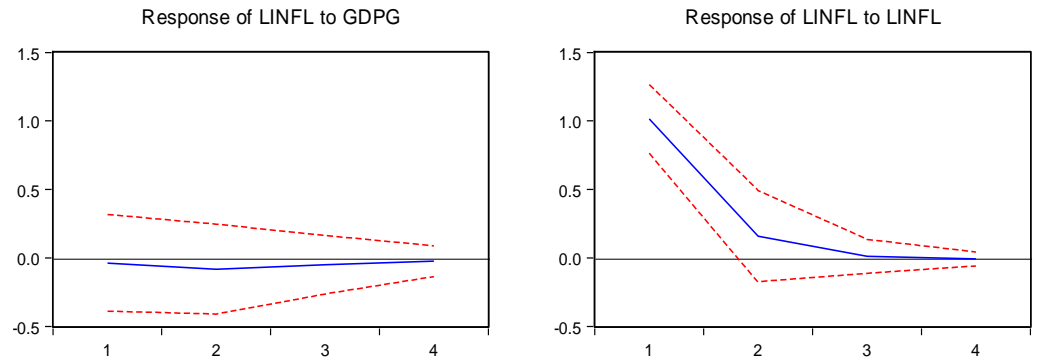

Response of LINFL to $\mathrm{FCl}$

Response of $\mathrm{FCl}$ to GDPG

Response of $\mathrm{FCl}$ to LINFL
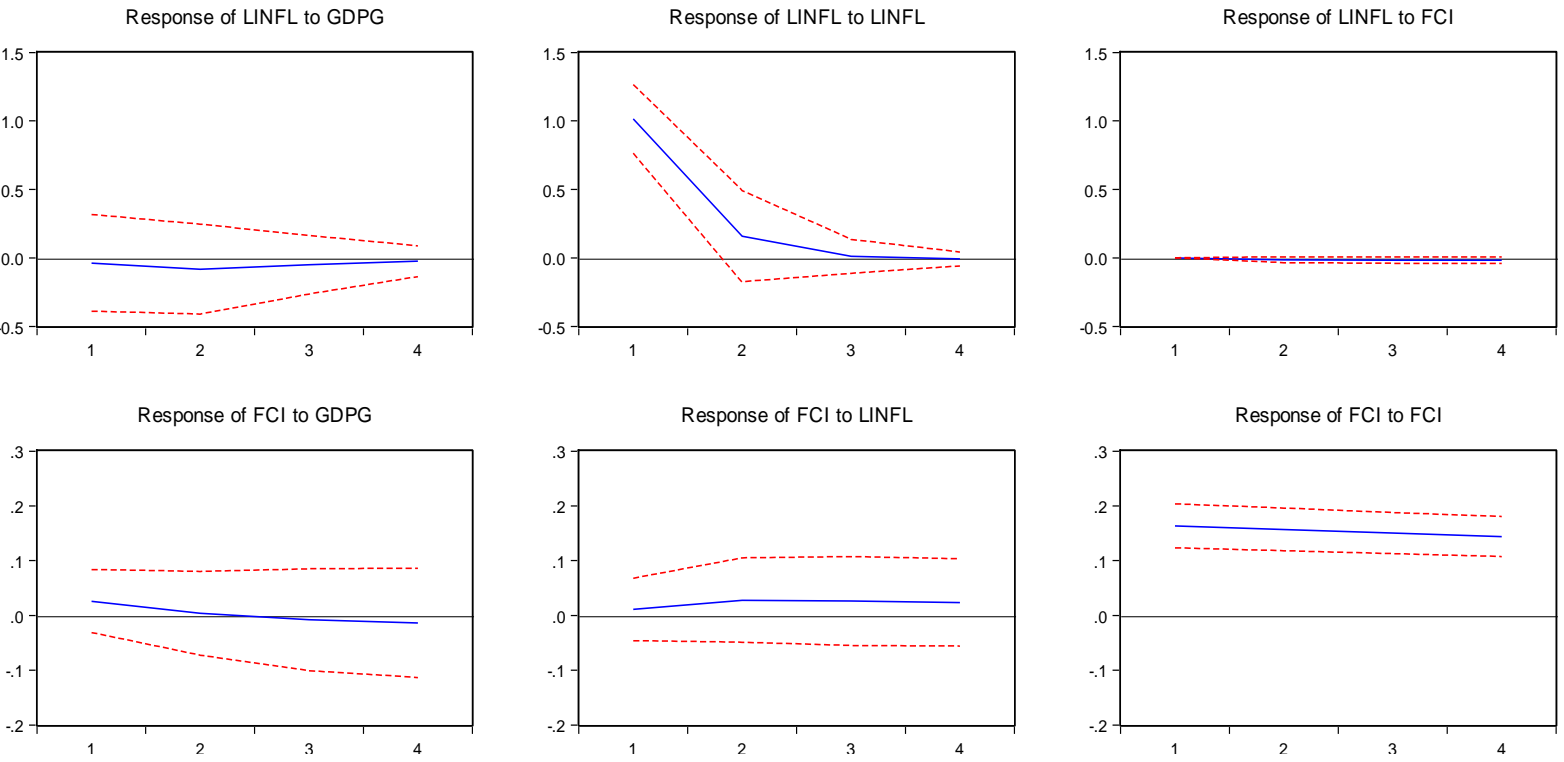

Response of $\mathrm{FCl}$ to $\mathrm{FCl}$

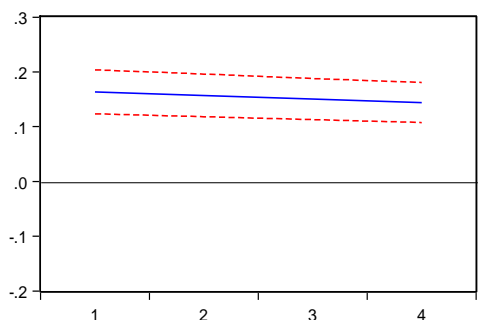

Figure 4. Impulse Response Function 

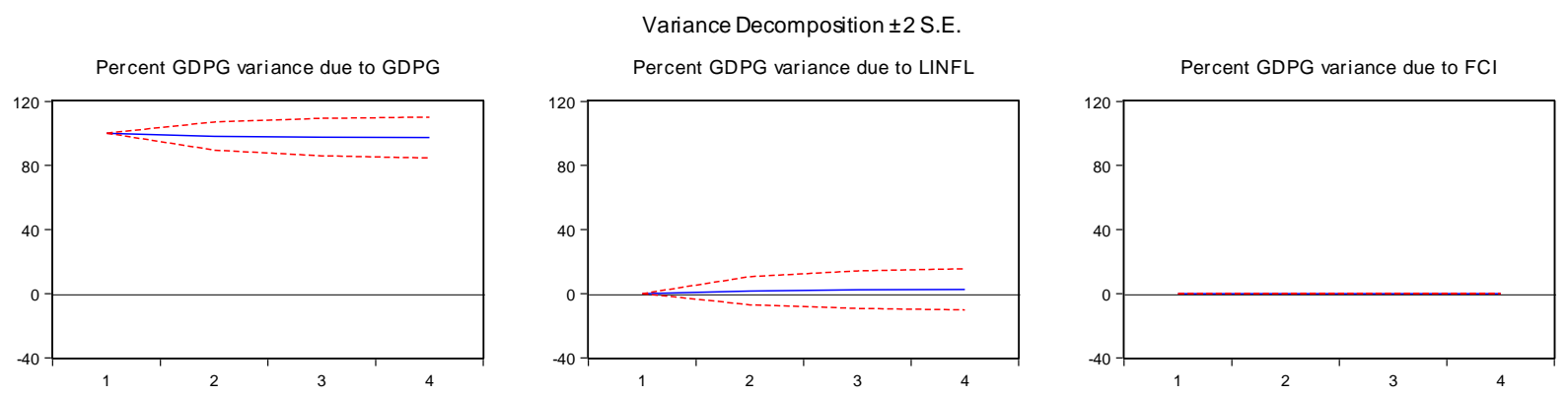

Percent LINFL variance due to GDPG

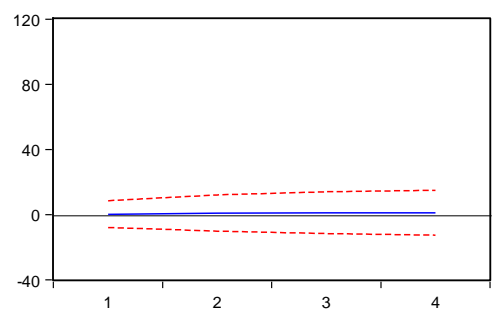

Percent LINFL variance due to LINFL

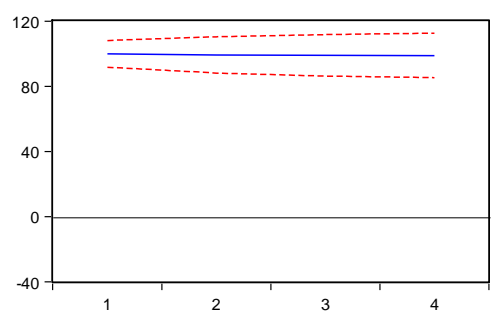

Percent LINFL variance due to $\mathrm{FCI}$

Percent $\mathrm{FCl}$ variance due to GDPG
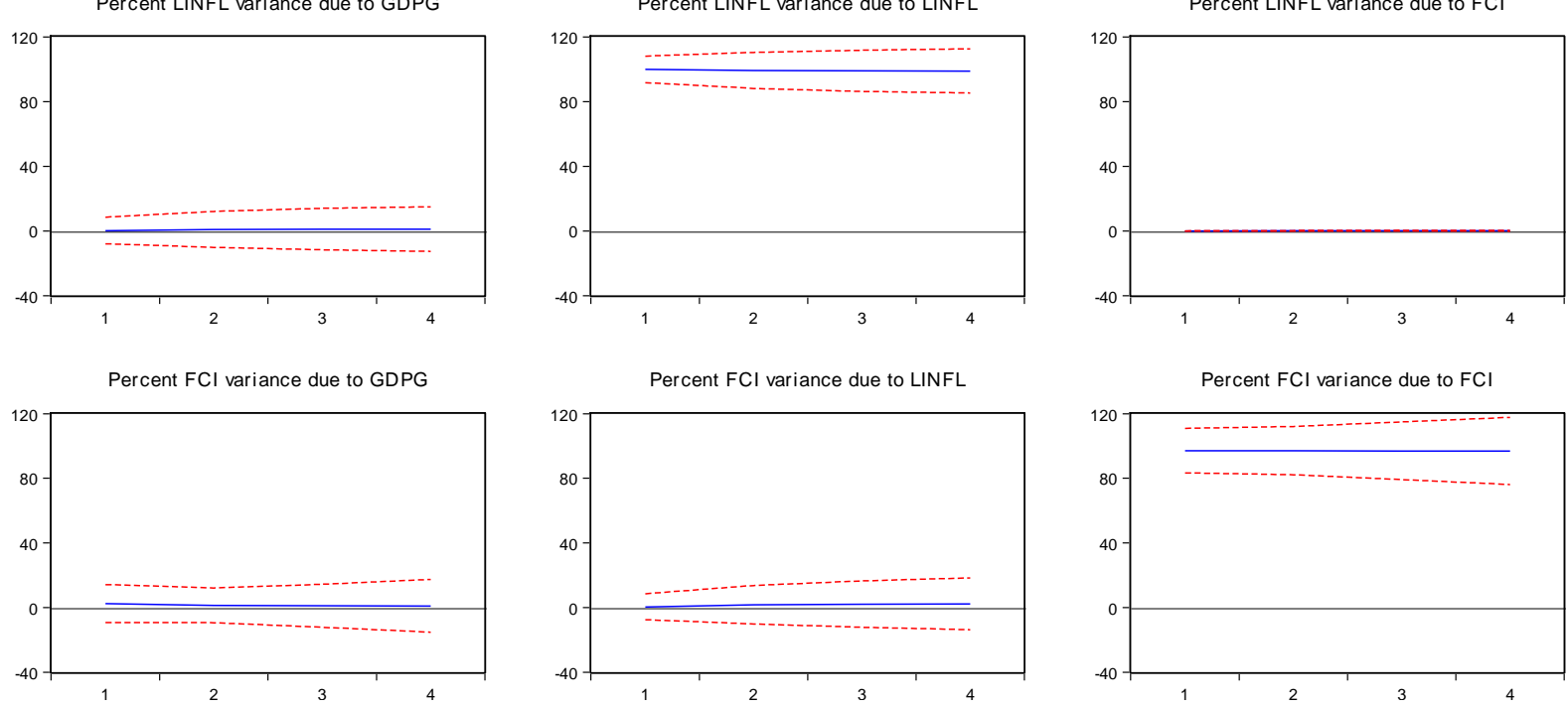

Percent $\mathrm{FCl}$ variance due to $\mathrm{FCl}$

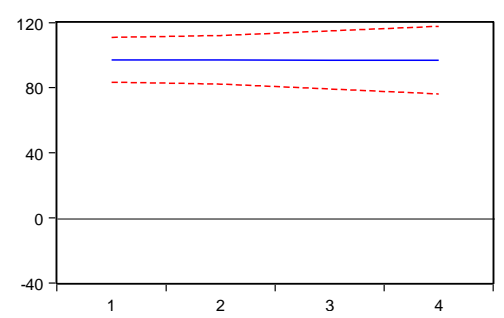

Figure 5. Forecast Error Variance Decomposition

\section{Conclusion}

In this paper, we constructed a financial conditions index for Nigeria and examine its predicting power for both economic growth and inflation rate using yearly time series data from 1985 to 2018. The variables included in the construction of the index are riskless interest rate, stock market index, exchange rate, credit to private sector and interest rate spread. While the weights attached to these variables are ARDL coefficients, the predictive power of the constructed index is examined within the VAR framework. We conclude as follows:

First, the results from the ARDL model shows that credit to private sector and stock market index are the most significant factors for nominal GDP, hence having a substantial weight in the resultant financial conditions index. However, the results from VAR impulse response function and forecast error variance decomposition suggest that the constructed financial conditions index contain very little information about future growth rate and inflationary trend.

\section{References}

Acaravci, A., Ozturk, I., \& Acaravci, S. K. (2007). Finance-growth nexus: Evidence from Turkey. International Research Journal of Finance and Economics, II, 30-40.

Al-Malkawi, H. A. N., \& Abdullah, N. (201I). Finance-growth nexus: evidence from a panel of MENA countries. International Research Journal of Finance and Economics, 63(63).

Angelopoulou, E., Balfoussia, H., \& Gibson, H. D. (2014). Building a financial conditions index for the euro area and selected euro area countries: what does it tell us about the crisis?. Economic Modelling, 38, 392-403.

Ibrahim, S., Abdullahi, A. B., Azman-Saini, W. N. W., \& Rahman, M. A. (2017). Finance-Growth Nexus: Evidence based on New Measures of Finance. International Journal of Economics \& Management, II(I).

Ipeghan, I. Y. O., \& Marshall, E. S. (2019). Modeling Capital Market Performance Indicators, Financial Development and Economic Growth in Nigeria: Empirical Evidence. 
Kabundi, A., \& Mbelu, A. (2020). Estimating a time-varying financial conditions index for South Africa. Empirical Economics, I-28.

Khundrakpam, J. K., Kavediya, R., \& Anthony, J. M. (2017). Estimating Financial Conditions Index for India. Journal of Emerging Market Finance, I6(I), 6I-89.

Ncanywa, T., \& Mabusela, K. (2019). Can financial development influence economic growth: The sub-Saharan analysis. Joumal of Economic and Financial Sciences, I2(I), I-I3.

Okunlola, O. A., Masade, E. O., Folaranmi Lukman, A., \& Ajayi Abiodun, S. (2020). Investigating Causal Relationship between Financial Development Indicators and Economic Growth: Toda and Yamamoto Approach. Iranian Economic Review, 24(I), 225-246.

Olaniyan, T. O. (2019). Interactive Effects of Remittances and Financial Sector Development on Economic Growth in Nigeria. Remittances Review, 4(1), 19-39.

Olayungbo, D. O., \& Quadri, A. (2019). Remittances, financial development and economic growth in sub-Saharan African countries: evidence from a PMG-ARDL approach. Financial Innovation, 5(I), 9.

Oro, O. U., \& Alagidede, P. (2018). The Nature of Finance-Growth Relationship: Evidence from a Panel of OilProducing Countries. Economic Analysis and Policy. Available at SSRN 3190069.

Schumpeter, J. A. (1912). 1934. The theory of economic development.

Swiston, A. (2008). A US financial conditions index: putting credit where credit is due(No. 8I6I). International Monetary Fund.

Wang, S., Xu, F., \& Chen, S. (2018). Constructing a dynamic financial conditions indexes by TVP-FAVAR model. Applied Economics Letters, 25(3), 183-186.

\section{Copyrights}

Copyright for this article is retained by the author(s), with first publication rights granted to the journal. This is an open-access article distributed under the terms and conditions of the Creative Commons Attribution license (http://creativecommons.org/licenses/by/4.0/). 